\section{'Tribeca' Hybrid Tomato; Fla. 8124C and Fla. 8249 Breeding Lines}

John W. Scott ${ }^{1}$

University of Florida, Gulf Coast Research and Education Center, 14625

CR 672, Wimauma, FL 33598

Stephen M. Olson

University of Florida, North Florida Research and Education Center, 155 Research Road, Quincy, FL 32351

Jerry A. Bartz

University of Florida, Plant Pathology, 1453 Fifield Hall, Gainesville, FL 32611
'Tribeca' is a fresh market hybrid tomato (Solanum lycopersicum L.) that has resistance to Tomato spotted wilt virus (TSWV) and heat-tolerant fruit setting (HT). 'Tribeca' has performed well on the peninsula of Florida where its ability to set fruit under high temperatures makes it an attractive cultivar choice even when TSWV is not a major production issue. It appears well adapted to the southeastern United States where TSWV has been problematic, and it has done well in trials in Turkey and some other eastern European countries. Inbred Fla. $8124 \mathrm{C}$ is the TSWV-resistant parent and has moderate HT. Inbred Fla. 8249, the other parent, has

\section{Origin}

The pedigree of 'Tribeca' hybrid, tested as Fla. 8363, is shown in Figure 1. Fla. 8249 is the seed parent and the main source of HT fruit setting. The HT is in the background of both parents that led to Fla. 8249. The HT of Fla. 7756 came from Fla. 7236 and the HT in the other parent could have come from Fla. 7324 and/or Fla. 7236. The HT of Fla. 7236 was derived from Fla. 7156, which in turn was derived from 'Campbell 28' (C28). Fla. 7324 is the HT parent in 'Equinox' (Scott et al., 1995). Besides HT, Fla. 8249 has the n-4 nipple-tip blossom scar that originated in NC 8276 (Barten et al., 1994). C9 is a neverripe inbred from a never-ripe line, Austin Fletcher, crossed with 'Florida MH-1' (MH1) (Crill et al., 1971). Other parents have been described previously: 648, 'Suncoast' (Scott et al., 1985), and 74VF18 (Scott et al., 1989). Fla. $8124 \mathrm{C}$ is an $\mathrm{F}_{7}$ inbred that was selected from the cross that became hybrid 'Fla. 7964' whose pedigree is published (Scott et al., 2004). It is the source of tomato spotted wilt resistance that traces back to the South Afri-

Received for publication 6 Nov. 2008. Accepted for publication 2 Dec. 2008.

Thanks to Cathy Provenzano, Jose Diaz, Jackie Snell, and Rosa Ayala for technical assistance.

${ }^{1}$ To whom reprint requests should be addressed; e-mail jwsc@ufl.edu. good $\mathrm{H}-7$ fruit setting ability. can cultivar Stevens (Stevens et al., 1996). Fla. $8124 \mathrm{C}$ also has moderate HT that traces to Fla. 7324, which was used as a recurrent parent three times as TSWV resistance was moved from 'Stevens'. Fla. 8124C has large fruit size that is derived from Fla. 7777, a large globe type with Fla. 7060 (Scott et al., 1989) and 'Suncoast' (Scott et al., 1985) in its background.

\section{Description}

'Tribeca' has a determinate $(s p)$ vine with medium vigor. Overall, maturity is earlymidseason with early production greater than heat-sensitive cultivars under hightemperature growing conditions. The jointed pedicels attach to fruit that are flat-round in shape, have uniform shoulders ( $u$ or $u g$ ), and have smooth blossom scars conferred in part by the $n-4$ gene from Fla. 8249 and the $n-2$ gene from Fla. 8124C (Barten et al., 1994). Fruit firmness is comparable to that of other cultivars presently grown in Florida and the southeast (Table 1). Exterior color of 'Tribeca' was relatively dark red as indicated by lower $\mathrm{L}$ values and hue angles compared with several Florida-grown cultivars (Table 1). The internal $\mathrm{L}$ and hue angle values were either comparable or less than those of commercial Florida cultivars indicating color to be similar or darker red, respectively. Fruit are usually free of white tissue formation in the pericarp, but some white tissue can form under fertilizer stress conditions. Fruit flavor has been rated by the senior author as $3=$ good on a 1 to 5 scale ranging from $1=$ poor to $5=$ excellent. Flavor would be in a similar range as that of widely grown Florida tomatoes such as 'Sebring', 'Florida 91', and 'Florida 47'. 'Tribeca' has had consistently good yield and fruit size in north Florida where TSWV is often a serious threat to production (Table 2). In Fall 2006, it was comparable to six cultivars, including five resistant to TSWV, for marketable total and extralarge fruit, percentage of marketable fruit, and fruit weight. In Spring 2007, TSWV was prevalent in the trial and yields of the two susceptible cultivars Phoenix and Florida 47 suffered compared with the resistant cultivars. 'Tribeca' had yields and fruit size comparable to the seven TSWV cultivars and was only less than 'Fletcher' for percentage of marketable fruit. In Fall 2007, the tomatoes were subjected to relatively severe heat stress and infection with Tomato yellow leaf curl virus. 'Tribeca' was numerically at the top of the trial for marketable yield; extralarge production was significantly greater than eight cultivars with only 'Bella Rosa' having similar production of

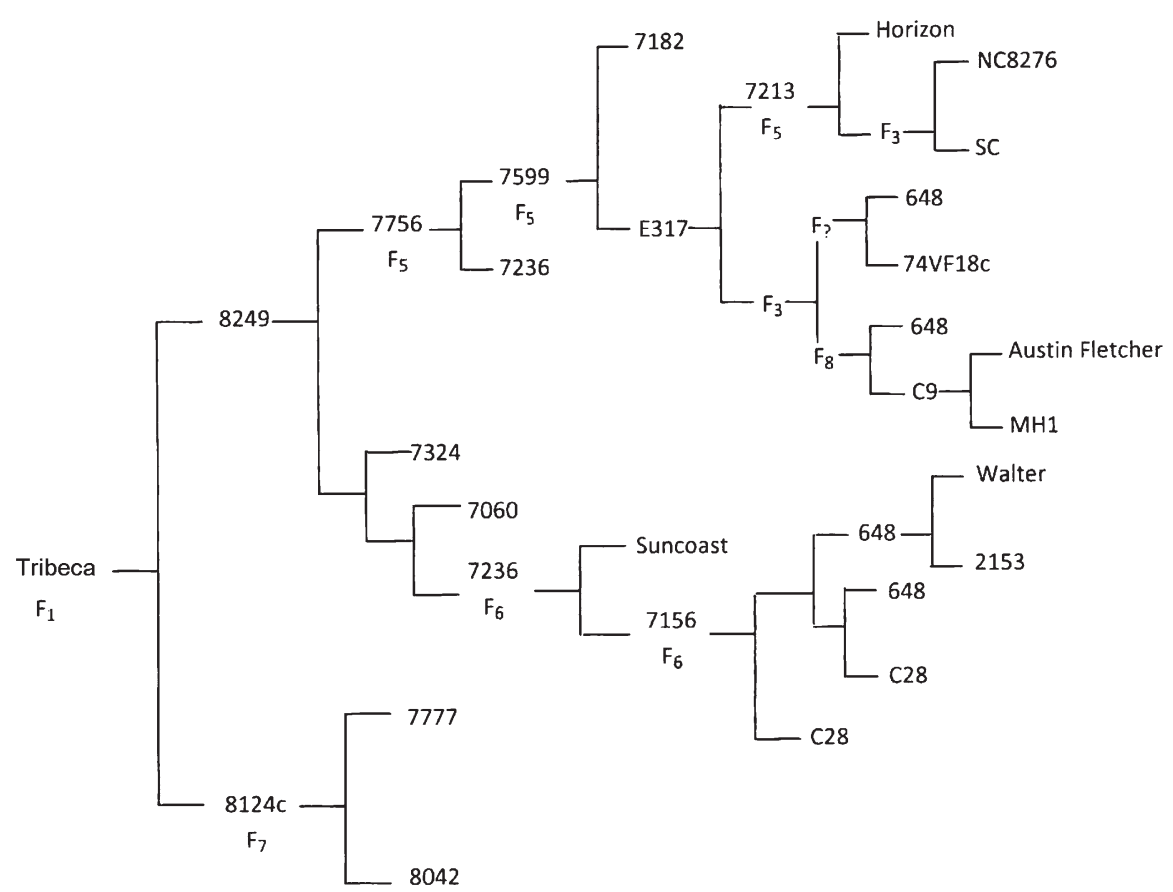

Fig. 1. Pedigree of 'Tribeca' hybrid tomato. 
Table 1. Firmness, external color, and internal color measurements for tomato hybrids grown over two seasons in Balm, FL.

\begin{tabular}{|c|c|c|c|c|c|c|}
\hline \multirow[b]{2}{*}{ Season } & \multirow[b]{2}{*}{ Hybrid } & \multirow{2}{*}{$\begin{array}{c}\text { Firmness } \\
\text { (mm deformation) }\end{array}$} & \multicolumn{2}{|c|}{ External color } & \multicolumn{2}{|c|}{ Internal color } \\
\hline & & & $\mathrm{L}$ & $\overline{\text { Hue angle }}$ & $\mathrm{L}$ & $\overline{\text { Hue angle }}$ \\
\hline \multirow[t]{4}{*}{ Fall 2006} & Florida 47 & $3.2 \mathrm{a}^{\mathrm{z}}$ & $42.7 \mathrm{a}$ & $45.6 \mathrm{a}$ & $40.3 \mathrm{~b}$ & $41.7 \mathrm{a}$ \\
\hline & Tribeca & $2.7 \mathrm{~b}$ & $40.2 \mathrm{c}$ & $42.8 \mathrm{~b}$ & $39.0 \mathrm{bc}$ & $40.9 \mathrm{a}$ \\
\hline & Florida 91 & $2.6 \mathrm{~b}$ & $41.4 \mathrm{~b}$ & $44.8 \mathrm{a}$ & $42.6 \mathrm{a}$ & $42.3 \mathrm{a}$ \\
\hline & Solar Fire & $2.4 \mathrm{~b}$ & $41.5 \mathrm{~b}$ & $45.6 \mathrm{a}$ & $38.1 \mathrm{c}$ & $39.0 \mathrm{~b}$ \\
\hline \multirow[t]{5}{*}{ Spring 2005} & Fla. 7964 & $3.4 \mathrm{a}$ & $40.2 \mathrm{~b}$ & $40.8 \mathrm{~d}$ & $42.4 \mathrm{a}$ & $41.5 \mathrm{~b}$ \\
\hline & Sebring & $2.6 \mathrm{~b}$ & $41.8 \mathrm{a}$ & $45.9 \mathrm{a}$ & $41.6 \mathrm{a}$ & $40.1 \mathrm{~b}$ \\
\hline & Florida 47 & $2.5 \mathrm{~b}$ & $41.5 \mathrm{a}$ & $44.5 \mathrm{~b}$ & $44.3 \mathrm{a}$ & $45.1 \mathrm{a}$ \\
\hline & Tribeca & $2.4 \mathrm{~b}$ & $40.1 \mathrm{~b}$ & $39.9 \mathrm{~d}$ & $41.9 \mathrm{a}$ & $42.0 \mathrm{~b}$ \\
\hline & Sanibel & $2.4 \mathrm{~b}$ & $41.2 \mathrm{a}$ & $42.4 \mathrm{c}$ & $44.3 \mathrm{a}$ & $45.2 \mathrm{a}$ \\
\hline
\end{tabular}

${ }^{\mathrm{z}}$ Mean separation in columns within season by Duncan's multiple range test at $P \leq 0.05$. at Quincy, FL, over three seasons.

\begin{tabular}{|c|c|c|c|c|}
\hline \multirow[b]{2}{*}{ Entry } & \multicolumn{2}{|c|}{ Marketable yield (11.3 kg cartons/ha) } & \multirow{2}{*}{$\begin{array}{l}\text { Marketable } \\
\text { (\% by wt.) }\end{array}$} & \multirow[b]{2}{*}{ Fruit wt. (g) } \\
\hline & Extra-large & Total & & \\
\hline \multicolumn{5}{|l|}{ Fall 2006} \\
\hline Quincy & $1,914 \mathrm{ab}^{\mathrm{z}}$ & $2,826 \mathrm{a}$ & $84.6 \mathrm{a}$ & $176 \mathrm{a}$ \\
\hline Bella Rosa & $2,019 \mathrm{a}$ & $2,485 a b$ & $79.3 \mathrm{a}$ & $190 \mathrm{a}$ \\
\hline Phoenix & $1,669 \mathrm{ab}$ & $2,209 \mathrm{ab}$ & $77.6 \mathrm{a}$ & $187 \mathrm{a}$ \\
\hline Tribeca & $1,737 \mathrm{ab}$ & $2,134 a b$ & $80.0 \mathrm{a}$ & $190 \mathrm{a}$ \\
\hline Amelia & $1,709 \mathrm{ab}$ & $2,115 \mathrm{ab}$ & $70.9 \mathrm{a}$ & $193 \mathrm{a}$ \\
\hline Red Defender & $1,293 \mathrm{ab}$ & $1,896 \mathrm{ab}$ & $76.4 \mathrm{a}$ & $170 \mathrm{a}$ \\
\hline Crista & $1,320 \mathrm{ab}$ & $1,745 \mathrm{ab}$ & $76.1 \mathrm{a}$ & $184 \mathrm{a}$ \\
\hline Florida 47 & $1,070 \mathrm{~b}$ & $1,480 \mathrm{~b}$ & $76.0 \mathrm{a}$ & $181 \mathrm{a}$ \\
\hline \multicolumn{5}{|l|}{ Spring 2007} \\
\hline Fletcher & $3,062 \mathrm{a}$ & $3,414 \mathrm{a}$ & $84.1 \mathrm{a}$ & $229 a b$ \\
\hline Quincy & $2,598 \mathrm{ab}$ & $2,851 \mathrm{ab}$ & $77.1 \mathrm{ab}$ & $232 \mathrm{ab}$ \\
\hline Tribeca & $2,552 \mathrm{ab}$ & $2,779 \mathrm{ab}$ & $70.9 \mathrm{bc}$ & $230 \mathrm{ab}$ \\
\hline Red Defender & $2,290 \mathrm{ab}$ & $2,597 \mathrm{ab}$ & $71.9 \mathrm{bc}$ & $196 \mathrm{~b}$ \\
\hline Mt. Glory & $2,334 \mathrm{ab}$ & $2,575 \mathrm{ab}$ & $78.1 \mathrm{ab}$ & $210 \mathrm{ab}$ \\
\hline Amelia & $2,340 \mathrm{ab}$ & $2,524 \mathrm{ab}$ & $79.2 \mathrm{ab}$ & $252 \mathrm{a}$ \\
\hline Bella Rosa & $2,311 \mathrm{ab}$ & $2,513 \mathrm{ab}$ & $71.2 \mathrm{bc}$ & $232 \mathrm{ab}$ \\
\hline Crista & $1,857 \mathrm{bc}$ & $2,127 \mathrm{bc}$ & $76.0 \mathrm{ab}$ & $213 a b$ \\
\hline Phoenix & $1,252 \mathrm{c}$ & $1,432 \mathrm{c}$ & $65.5 \mathrm{c}$ & $221 \mathrm{ab}$ \\
\hline Florida 47 & $435 \mathrm{~d}$ & $567 \mathrm{~d}$ & $50.0 \mathrm{~d}$ & $198 \mathrm{~b}$ \\
\hline \multicolumn{5}{|l|}{ Fall 2007} \\
\hline Tribeca & $1,226 \mathrm{a}$ & $1,631 \mathrm{a}$ & $74.7 \mathrm{a}$ & 193 a \\
\hline Red Defender & $815 \mathrm{bc}$ & $1,556 \mathrm{a}$ & $69.5 \mathrm{a}-\mathrm{c}$ & $162 \mathrm{~d}$ \\
\hline Bella Rosa & $1,122 \mathrm{ab}$ & $1,533 \mathrm{ab}$ & $68.0 \mathrm{a}-\mathrm{c}$ & $193 \mathrm{a}$ \\
\hline Quincy & $755 \mathrm{bc}$ & $1,196 \mathrm{ab}$ & $71.4 \mathrm{ab}$ & $179 \mathrm{a}-\mathrm{d}$ \\
\hline Crista & $770 \mathrm{bc}$ & $1,161 \mathrm{ab}$ & $68.8 \mathrm{a}-\mathrm{c}$ & $184 \mathrm{ab}$ \\
\hline Phoenix & $712 \mathrm{c}$ & $1,072 \mathrm{~b}$ & $61.5 \mathrm{bc}$ & $181 \mathrm{a}-\mathrm{c}$ \\
\hline Fletcher & $485 \mathrm{c}$ & $940 \mathrm{~b}$ & $63.8 \mathrm{bc}$ & $162 \mathrm{~d}$ \\
\hline Florida 47 & $454 \mathrm{c}$ & $833 \mathrm{~b}$ & $65.3 \mathrm{a}-\mathrm{c}$ & $164 \mathrm{~cd}$ \\
\hline Amelia & $590 \mathrm{c}$ & $818 \mathrm{~b}$ & $61.6 \mathrm{bc}$ & $190 \mathrm{ab}$ \\
\hline Mt. Glory & $469 \mathrm{c}$ & $790 \mathrm{~b}$ & $61.4 \mathrm{c}$ & $170 \mathrm{~b}-\mathrm{d}$ \\
\hline
\end{tabular}

${ }^{\mathrm{z}}$ Mean separation in columns within season by Duncan's multiple range test, at $P \leq 0.05$, based on a larger number of entries.

Table 3. Marketable yield, fruit size, and culls for selected tomato hybrids in Fall 2006 at Balm, FL.

\begin{tabular}{lccc}
\hline Hybrids & $\begin{array}{c}\text { Marketable yield } \\
(11.3 \mathrm{~kg} \text { cartons/ha })\end{array}$ & $\begin{array}{c}\text { Fruit size } \\
(\mathrm{g})\end{array}$ & $\begin{array}{c}\text { Culls } \\
(\% \mathrm{by} \mathrm{wt})\end{array}$ \\
\hline Fla. 8367 & $2,981 \mathrm{a}^{\mathrm{z}}$ & $232 \mathrm{a}-\mathrm{c}$ & $15 \mathrm{~d}$ \\
Fla. 8314 & $2,537 \mathrm{ab}$ & $204 \mathrm{~cd}$ & $17 \mathrm{~d}$ \\
Tribeca & $1,964 \mathrm{a}-\mathrm{c}$ & $207 \mathrm{~cd}$ & $26 \mathrm{~cd}$ \\
Scarlet Red & $1,808 \mathrm{bc}$ & $204 \mathrm{~cd}$ & $35 \mathrm{bc}$ \\
Florida 47 & $1,549 \mathrm{~b}-\mathrm{d}$ & $187 \mathrm{~d}$ & $34 \mathrm{bc}$ \\
Solar Fire & $1,366 \mathrm{~b}-\mathrm{d}$ & $215 \mathrm{~b}-\mathrm{d}$ & $19 \mathrm{~cd}$ \\
Sebring & $1,215 \mathrm{~cd}$ & $218 \mathrm{~b}-\mathrm{d}$ & $31 \mathrm{c}$ \\
Crista & $1,166 \mathrm{~cd}$ & $204 \mathrm{~cd}$ & $50 \mathrm{ab}$ \\
Phoenix & $1,154 \mathrm{~cd}$ & $261 \mathrm{a}$ & $27 \mathrm{~cd}$ \\
Florida 91 & $474 \mathrm{~d}$ & $249 \mathrm{ab}$ & $52 \mathrm{a}$ \\
\hline
\end{tabular}

${ }^{\mathrm{z}}$ Mean separation in columns by Duncan's multiple range test at $P \leq 0.05$. extralarge fruit. Total yield was comparable to four cultivars and significantly more than the other five. The percentage of marketable fruit and fruit size for 'Tribeca' was comparable to four cultivars and greater than five others (Table 2). 'Tribeca' also performed well in a yield trial at GCREC in Fall 2006 (Table 3). TSWV has not been problematic on the Florida peninsula, but 'Tribeca' may be useful there for its HT alone. The HT of 'Tribeca' is evident in the relatively good performance in the fall crops (Tables 2 and 3). Fla. 8124C has globe-shaped fruit, whereas Fla. 8249 has medium-large, flat-round fruit.

\section{Disease Resistance}

Resistance to TSWV is conferred by the $S w-5$ gene, which is heterozygous in 'Tribeca' (Table 4). Fla. $8124 \mathrm{C}$ is the source of the $S w-5$ gene as indicated by the linked molecular marker CT220F/R (Fig. 2). The hybrid is homozygous-resistant to fusarium wilt races 1 and 2 incited by Fusarium oxysporum f. sp. lycopersici (Sacc.) Snyder \& Hansen (I, I-2 genes); homozygous-resistant to Gray leafspot incited by Stemphyllium spp. Webber (Sm gene); and heterozygous-resistant to verticillium wilt race 1 incited by Verticillium dahliae Kleb. (Ve gene). Fla. $8124 \mathrm{C}$ is the source of resistance to verticillium wilt because Fla. 8249 is susceptible. Stem scar water uptake for 'Tribeca' and Fla. 8249 appeared to be low (Table 5), which would indicate tolerance to bacterial soft rot incited by Erwinia carotovora Jones (Smith et al., 2008). However, in an earlier experiment, Fla. 8124C had high stem scar water uptake (Scott and Bartz, unpublished data). A hybrid like 'Tribeca' between low (Fla. 8249) and high (Fla. 8124C) water uptake parents would be predicted to have intermediate uptake (Smith et al., 2008). Further testing is needed to determine if water uptake is low or intermediate for 'Tribeca'. 'Tribeca' is tolerant to most common fruit disorders, including graywall where little to none has been seen under conditions conducive to this disorder. Fla. $8124 \mathrm{C}$ has only moderate tolerance to graywall, whereas Fla. 8249 appears highly tolerant. There is some zippering in both parents and the hybrid, but zippering expression is usually not excessive. 'Tribeca' and its

Table 4. Tomato spotted wilt virus (TSWV) incidence for tomato hybrids at Quincy, FL, Spring 2007.

\begin{tabular}{lcc}
\hline Hybrid $^{z}$ & Plant no. & $\begin{array}{c}\text { TSWV } \\
\text { incidence }(\%)\end{array}$ \\
\hline Fletcher & 48 & 0 \\
BHN 44 & 48 & 0 \\
BHN 602 & 48 & 0 \\
Tribeca & 48 & 0 \\
Red Defender & 48 & 0 \\
Phoenix & 48 & 65 \\
Florida 47 & 48 & 82 \\
\hline
\end{tabular}

zPhoenix and Florida 47 are susceptible, the others are resistant ( $S w-5$ gene). 


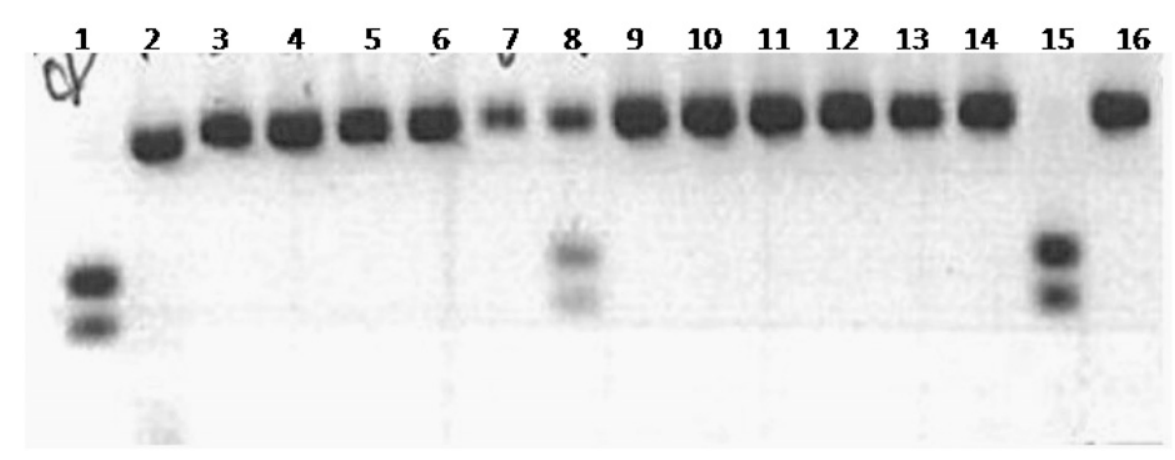

Fig. 2. Polymerase chain reaction fragments with primer CT220F/R cut with $A s e T$. Lanes 1 and 15 are 'Horizon', the Tomato spotted wilt virus (TSWV)-susceptible control. Lanes 2 and 16 are Fla. 8251, the TSWV-resistant control. Lane 8 is Fla. $8124 \times$ Fla. 7946, a heterozygous-resistant hybrid, and Lanes 3 to 7 and 9 to 14 are from individual plants of Fla. 8124C. For information on this marker, tightly linked to the $S w-5$ locus, see Garland et al. (2005).

Table 5. Water uptake for mature green fruit of tomato genotypes grown at Balm, FL, Fall 2007.

\begin{tabular}{lc}
\hline Cultigen & Water uptake \\
\hline Florida 91 & $1.50 \mathrm{a}^{\mathrm{y}}$ \\
Florida 47 & $1.34 \mathrm{ab}$ \\
Fla. 8249 & $1.21 \mathrm{bc}$ \\
Sanibel & $1.10 \mathrm{bc}$ \\
Tribeca & $1.05 \mathrm{c}$ \\
Solar Fire & $0.99 \mathrm{c}$ \\
\hline
\end{tabular}

${ }^{\mathrm{z}}$ Fruit submerged in water at 3 psi for $2 \mathrm{~min}$ in a pressure cooker. Data are (wt. out-wt. in/wt. in)* 100.

${ }^{y}$ Mean separation in columns by Waller-Duncan Kratio $t$ test at $P \leq 0.05$.

parents have good tolerance to all types of fruit cracking and this has been evident in the high percentage of marketable fruit that was reported previously.

\section{Availability}

Seed of 'Tribeca', Fla. 8124C, and Fla. 8249 are being released through Florida Foundation Seed Producers Inc., Greenville, FL 32443 (http://ffsp.net). Vilmorin seed company has been given exclusive rights to produce commercial seed of 'Tribeca'. Small quantities of seed for research purposes are

\section{Literature Cited}

Barten, J.H.M., J.W. Scott, and R.G. Gardner. 1994. Characterization of blossom-end moravailable from J.W. Scott. phology genes in tomato and their usefulness in breeding for smooth blossom-end scars. J. Amer. Soc. Hort. Sci. 119:798-803.

Crill, P., J.W. Strobel, D.S. Burgis, H.H. Bryan, C.A. John, P.H. Everett, J.A. Bartz, N.C Hayslip, and W.W. Deen. 1971. Florida MH1, Florida's first machine harvest fresh market tomato. Fla. Ag. Exp. Sta. Circ. S-212:1-12.

Garland, S., M. Sharman, D. Persley, and D. McGrath. 2005. The development of an improved PCR-based marker system for $\mathrm{Sw}-5$, an imporant TSWV resistance gene of tomato. Australian Journal of Agricultural Research 56:285-289.

Scott, J.W., P.H. Everett, H.H. Bryan, D.D. Gull, T.K. Howe, P.J. Stoffella, and R.B. Volin. 1985. 'Suncoast' - A large-fruited home garden tomato. Fla. Agr. Exp. Sta. Circ. S-322:1-7.

Scott, J.W., S.M. Olson, J.A. Bartz, D.N. Maynard, and P.S. Stofella. 2004. Fla. 7964 hybrid tomato resistant to spotted wilt virus. Rpt. Tomato Genet. Coop. 54:51.

Scott, J.W., S.M. Olson, H.H. Bryan, T.K. Howe, P.J. Stoffella, and J.A. Bartz. 1989. Solar Set: A heat tolerant, fresh market tomato hybrid. Fla. Agr. Exp. Sta. Circ. S-359:1-10.

Scott, J.W., S.M. Olson, T.K. Howe, P.J. Stoffella, J.A. Bartz, and H.H. Bryan. 1995. 'Equinox' heat-tolerant hybrid tomato. HortScience 30:647-648.

Smith, S.M., J.W. Scott, J.A. Bartz, and S.A. Sargent. 2008. Diallel analysis of fruit water absorption in tomato, a contributing factor in postharvest decays. J. Amer. Soc. Hort. Sci. 133:55-60.

Stevens, M.R., D.K. Heiny, D.D. Rhoads, P.D. Griffiths, and J.W. Scott. 1996. A linkage map of the tomato spotted wilt virus resistance gene $S w-5$ using near isogenic lines and an interspecific cross. International Symposium on Tospoviruses and Thrips of Floral and Vegetable Crops, Taichung, Taiwan, Nov. 7-11, 1995. Acta Hort. 43:385-392. 